\title{
Pemanfaatan Digital Marketing sebagai Sarana Komersialisasi Produk Kampung Batik Kembang Turi Blitar
}

\author{
Rani Arifah Normawati*1, Shanti Ike Wardani ${ }^{2}$, Anna Widayani ${ }^{3}$ \\ 1,2,3 Akademi Komunitas Negeri Putra Sang Fajar Blitar \\ ${ }^{123}$ Program Studi Administrasi Server dan Jaringan Komputer, Kekhususan Otomasi Perkantoran, \\ Akademi Komunitas Negeri Putra Sang Fajar Blitar \\ *e-mail: raniarifah@akb.ac.id¹ ${ }^{1}$, shanti@akb.ac.id², annawidayani@akb.ac.id ${ }^{3}$
}

\begin{abstract}
Digital marketing is the result of the integration of traditional marketing concepts with digital elements. Digitalization in various forms is positively related to the growth, performance, and competitiveness of small businesses. Kampung Batik Kembang Turi Blitar is a business that was established to empower citizens and preserve cultural heritage. The existence of Kampung Batik Kembang Turi Blitar is not widely known by the public. Marketing of its products is still using a simple method and not yet utilizing online marketing. Community service is carried out by assisting in utilizing digital marketing as a means of commercialization of Blitar Blitar Blitar Batik Village products. Through this activity, it is hoped that Batik Kembang Turi Blitar Blitar Village can commercialize its products through digital marketing by utilizing various means such as social media and E-commerce. The results of this activity are an increase in understanding related to digital marketing, increased skills in the use of social media and E-commerce, and motivation to implement digital marketing in Kampung Batik Kembang Turi Blitar Blitar.
\end{abstract}

Keywords: Digital marketing, commercialization, small business

\begin{abstract}
Abstrak
Digital marketing merupakan hasil integrasi konsep pemasaraan tradisional dengan elemen digital. Digitalisasi dalam berbagai bentuk berhubungan positif dengan pertumbuhan, kinerja dan daya saing usaha kecil. Kampung Batik Kembang Turi Blitar adalah usaha yang didirikan dengan tujuan memberdayakan warga dan melestarikan warisan budaya. Keberadaan Kampung Batik Kembang Turi Blitar belum banyak dikenal masyarakat luas. Pemasaran produknya masih menggunakan cara sederhana dan belum memanfaatkan pemasaran secara online. Pengabdian kepada masyarakat ini dilakukan dengan memberikan pendampingan dalam memanfaatkan digital marketing sebagai sarana komersialisasi produk Kampung Batik Kembang Turi Blitar Blitar. Melalui kegiatan ini diharapkan Kampung Batik Kembang Turi Blitar Blitar mampu mengkomersilkan produknya melalui digital marketing dengan memanfaatkan berbagai sarana misalnya social media dan E-commerce. Hasil kegiatan ini adalah peningkatan pemahaman terkait digital marketing, peningkatan ketrampilan penggunaan social media dan E-commerce, dan motivasi untuk mengimplementasikan digital marketing di Kampung Batik Kembang Turi Blitar Blitar.
\end{abstract}

Kata kunci: Digital marketing, komersialisasi, usaha kecil

\section{PENDAHULUAN}

Blitar Raya merupakan salah satu wilayah di Jawa Timur yang telah dikenal dengan potensi wisata unggulan, baik wisata sejarah, budaya maupun wisata alam. Pengembangan wisata di kota dan kabupaten Blitar mendapatkan dukungan penuh dari Pemerintah Kota dan Pemerintah Kabupaten Blitar. Hal ini ditunjukkan oleh arah kebijakan pemerintah melalui pengembangan infrastruktur wisata dan pengoptimalan potensi wisata yang ada dengan mengembangkan wisata desa dimana desa-desa harus memiliki minimal satu obyek wisata.

Kelurahan Turi adalah salah satu kelurahan di kota Blitar yang mengembangkan wisatanya dengan mendirikan kampung batik, bernama Kampung Batik Kembang Turi Blitar yang berlokasi di jalan Turi No. 63 kelurahan Turi kecamatan Sukorejo kota Blitar. Kampung batik tersebut dirancang dengan ide utama yaitu memberdayakan warga, terutama para ibu rumah tangga yang mempunyai banyak waktu luang. Pemerintah setempat memfasilitasinya dengan 
memberikan pelatihan membatik sehingga dengan ketrampilan tersebut, para ibu rumah tangga dapat lebih produktif.

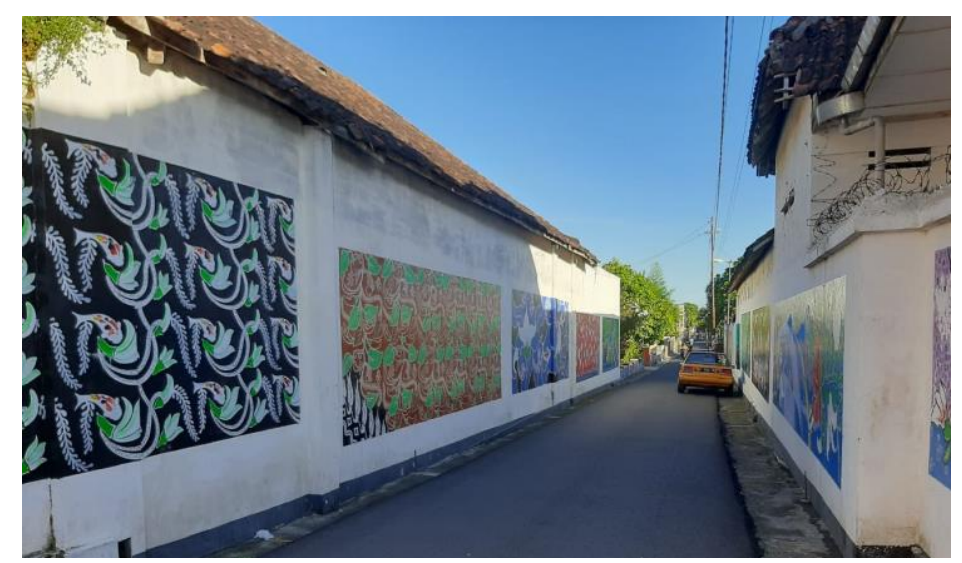

Gambar 1. Kampung Batik Kembang Turi Blitar

Selain dalam rangka pemberdayaan masyarakat, tujuan lain dibentuknya Kampung Batik Kembang Turi Blitar adalah untuk melestarikan warisan budaya nasional, yaitu batik. Batik sendiri telah ditetapkan oleh UNESCO sebagai Warisan Kemanusiaan untuk Budaya Lisan dan Non-bendawi (Masterpieces of the Oral and Intangible Heritage of Humanity) sejak 2 Oktober 2009. Di Indonesia, setiap daerah memiliki batik khas masing-masing. Begitu pula di Blitar. Blitar memiliki batik khas yaitu batik tutur, dalam bahasa Jawa berarti pitutur atau nasehat yang sarat akan makna filosofis, yang digambarkan dengan binatang atau hewan sebagai unsur ornamen utama (Mengenal Batik Tutur, Batik Khas Blitar Warisan Nenek Moyang - BALITAR.ID, n.d.). Sedangkan di Kampung Batik Kembang Turi Blitar, motif ikan Koi dan kembang Turi menjadi ciri khas produknya. Motif ikan Koi diangkat karena merupakan ciri khas kota Blitar sebagai penghasil ikan Koi, sedangkan kembang Turi mewakili nama kelurahan tempat didirikan Kampung Batik Kembang Turi.

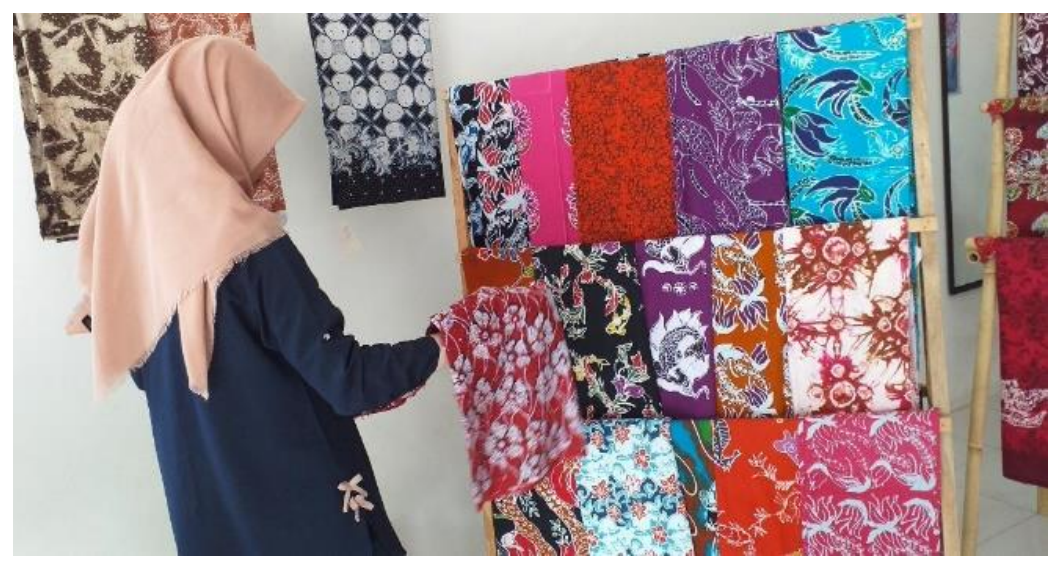

Gambar 2. Produk khas Kampung Batik Kembang Turi Blitar

Untuk mendukung produktivitas tersebut, dibangun pula galeri batik yang digunakan sebagai tempat memamerkan batik yang dihasilkan. Tidak hanya itu, pendirian paguyuban bagi para pembatik juga diinisiasi untuk mendukung manajemen dan operasional di Kampung Batik Kembang Turi Blitar. Adapun jumlah anggota paguyuban Kampung Batik Kembang Turi Blitar adalah sebanyak 31 orang, dengan struktur dan kelembagaan yang telah disahkan melalui Surat Keputusan Kemenkumham dan akta notaris. 
Sebagai usaha yang baru berdiri dan untuk mengoptimalkan potensi wisata Kampung Batik Kembang Turi Blitar, diperlukan media komunikasi kepada publik agar keberadaannya semakin dikenal masyarakat luas. Selain itu diperlukan pula media yang dapat digunakan sebagai sarana komersialisasi produk-produknya untuk mendukung penjualan hasil produknya.

Teknologi informasi berkembang sangat dinamis. Perkembangan tersebut membawa perubahan pada berbagai tatanan kehidupan masyarakat, terlebih dalam bidang ekonomi. Konsep ekonomi digital lahir seiring perkembangan teknologi informasi, yang muncul sebagai gelombang ekonomi baru. Terminologi ekonomi digital digambarkan tentang bagaimana teknologi internet mentransformasikan proses bisnis, cara produk dan layanan dibuat dan dipasarkan, struktur dan tujuan perusahaan, dinamika persaingan, dan semua aturan untuk kesuksesan bisnis (Bukht \& Heeks, 2018).

Digitalisasi sendiri telah menjadi bagian keseharian kita saat ini. Realita bahwa masyarakat dari berbagai kalangan usia, gender, kelas sosial, ekonomi dan budaya dapat berinteraksi satu sama lain tanpa dibatasi oleh ruang dan waktu dan meningkatnya kepemilikan smartphone, telah mengubah perilaku konsumen saat ini. (Pandey et al., 2020) menyatakan bahwa digital marketing menawarkan penargetan yang tepat bagi calon pelanggan. Hal ini berarti pemanfaatan digital marketing mempermudah pelaku usaha untuk berinteraksi langsung dengan pelanggan, sehingga memotong jalur komunikasi antara perusahaan atau pelaku usaha dan pelanggan yang ada sebelumnya, melihat keterlibatan konsumen secara real time serta memungkinkan menyajikan konten yang sesuai dengan preferensi pelanggan. Proses tersebut disinyalir dapat meningkatkan produktivitas penjualan (Pandey et al., 2020). Digital marketing dianggap memiliki kelebihan dibanding pemasaran tradisional diantaranya (i) jaringan komunikasi berbiaya rendah menggunakan teknologi dan internet, (ii) aplikasi dan sumber daya manusia yang memungkinkan bisnis dilakukan melalui infrastruktur jaringan ini, (iii) pasar elektronik yang saling terhubung yang beroperasi melalui infrastruktur jaringan dan aplikasi, (iii) perantara dan produsen menyediakan berbagai produk dan layanan digital untuk memfasilitasi efisiensi dan likuiditas pasar, dan (iv) kebijakan dan kerangka hukum yang muncul untuk melakukan bisnis di dunia maya (Zekos, 2003).

Social media merupakan salah satu media komunikasi yang muncul pada era perkembangan teknologi informasi. Data yang dilansir oleh We are Social, sebuah agensi digital marketing di Amerika, menyebutkan bahwa platform social media yang paling banyak digunakan di Indonesia per Januari 2017 adalah Youtube (49\%), Facebook (48\%) dan Instagram (39\%) selanjutnya disusul oleh penggunaan Twitter (38\%), Whatsapp (38\%), dan Google (36\%). Sisanya ditempati secara berurutan oleh FB Messenger, Line, Linkedin, BBM, Pinterest, dan Wechat (Social media use jumps in Q1 despite privacy fears - We Are Social, n.d.). Sementara itu, Sri Widowati, Country Head Facebook Indonesia, menyampaikan bahwa pengguna Facebook di Indonesia membuka halaman Faceboook milik mereka rata-rata 80 kali sehari. Ia juga mengungkap bahwa sebanyak 45\% pengguna internet di Indonesia lebih suka berbelanja secara online. Forrester Research dan Nielsen dalam Taiminen \& Karjaluoto, 2015 menyebutkan bahwa konsumen saat ini lebih banyak menghabiskan waktu secara online dan menggunakan social media mereka dalam berinteraksi (Taiminen \& Karjaluoto, 2015).

Social media dapat digunakan untuk membangun komunitas bagi para pengguna produk atau layanan dengan tujuan untuk membangun hubungan dan menciptakan komunikasi dua arah, sehingga pelaku usaha dapat mendengar dan mengetahui langsung apa yang menjadi kebutuhan dan keinginan para konsumennya. Social media memiliki sifat penting yaitu komunikasi dua arah dengan pelanggan, dimana secara alami pelanggan mengharapkan cerita otentik dari pelanggan lain, dan informasi nyata lainnya yang merupakan percakapan disekitar merek (Taiminen \& Karjaluoto, 2015). Interaksi melalui internet berdampak positif pada performa perusahaan dengan meningkatkan perhatian pelanggan, mengembangkan hubungan yang lebih kuat dan sehingga mampu meningkatkan kepuasan pelanggan secara keseluruhan. Social media tampaknya menjadi alat yang berhasil untuk membangun merek serta menarik pelanggan dan membangun hubungan pelanggan yang unik. Sebuah penelitian terbaru menunjukkan bahwa 
dalam beberapa kasus, pemanfaatan social media juga dapat mendorong hasil langsung terkait penjualan (Taiminen \& Karjaluoto, 2015). Dengan bantuan social media, pelaku usaha dapat meningkatkan pertumbuhan jumlah pelanggan mereka (Balan \& Rege, 2017).

E-commerce menurut OECD 2009 dalam Statistik E-commerce 2019 yang dipublikasikan oleh Badan Pusat Statistik merupakan penjualan atau pembelian barang atau jasa, yang dilakukan melalui jaringan komputer dengan metode yang secara spesifik dirancang untuk tujuan menerima atau melakukan pesanan (Statistik, 2019). Peluang perdagangan elektronik menawarkan persiangan dalam skala internasional. Terdapat pertumbuhan yang fenomenal terkait komersialisasi melalui internet dalam beberapa waktu terakhir (Soliman \& Youssef, 2003). Selama tahun 2018 jumlah transaksi E-commerce yaitu sebanyak 24.821.916 transaksi dengan nilai transaksi yang mencapai 17,21 triliun rupiah. Perkembangan E-commerce baik dari segi transaksi maupun jumlah usaha yang tergabung di dalamnya, menjadi fokus perhatian pemerintah dengan dikeluarkannya Paket Kebijakan Ekonomi XIV mengenai E-commerce. Kebijakan ini diharapkan dapat mendukung visi pemerintah untuk menempatkan Indonesia sebagai negara dengan kapasitas digital ekonomi terbesar di Asia Tenggara pada 2020 (Statistik, 2019). Tidak hanya itu, pesatnya pertumbuhan E-commerce di Indonesia menjadi sorotan para venture capital dunia. Tercatat dalam pada Desember 2017, nilai investasi yang masuk ke Indonesia pada periode Januari hingga Agustus 2017 telah mencapai US\$ 3 miliar yang berarti porsi ini lebih dari seperlima nilai investasi di Asia Tenggara. Investasi ini diwujudkan dengan bermunculannya platform E-commerce di Indonesia. Berdasarkan riset yang dilakukan oleh iprice group, melalui metodologi Google Trends, terungkap pemain E-commerce mana saja yang paling banyak dicari selama tahun 2017. Lazada dan Tokopedia berada di posisi pertama dan kedua sebagai E-commerce yang paling banyak dicari di tahun 2017 dan disusul oleh Bukalapak serta Shopee yang merupakan pemain baru di dunia E-commerce, namun saat ini gencar melakukan periklanan kepada masyarakat (Inilah e-Commerce yang Paling Banyak Dikunjungi di 2017 / Marketeers - Majalah Bisnis \& Marketing Online - Marketeers.com, n.d.). Kehadiran para pemain tersebut semakin membuka kesempatan komersialisasi produk secara digital bagi para pelaku usaha.

Dalam beberapa literatur menunjukkan bahwa digitalisasi dalam berbagai bentuknya berhubungan positif dengan pertumbuhan, kinerja dan daya saing usaha kecil. Pemasaran digital dan media sosial memberikan peluang bagi usaha kecil untuk menarik pelanggan baru dan menjangkau pelanggan yang sudah ada secara lebih efisien. Bahkan titik awal digitalisasi, telah terbukti membawa peluang signifikan bagi usaha kecil dalam menjangkau target baru, meningkatkan kinerja dan efisiensi dan meningkatkan pertumbuhan dan daya saing (Taiminen \& Karjaluoto, 2015). Usaha kecil semakin banyak yang menggunakan social media. Pertumbuhan social media telah meningkatkan jumlah data yang dihasilkan dan ini dapat memberikan wawasan lebih lanjut kepada para pelaku usaha (Balan \& Rege, 2017). Berkaca pada fenomena tersebut, upaya komersialisasi produk mau tidak mau harus mengimplementasikan konsep digital marketing. Peluang, kemudahan serta manfaat yang ditawarkan dari implementasi digital marketing harus disikapi dengan baik oleh para pelaku usaha yaitu dengan cara melakukan adopsi teknologi (Balan \& Rege, 2017).

Potensi pemanfaatan digital marketing mengharuskan para pelakunya mengenal, terinspiransi, mempunyai motivasi dan melek teknologi. Pelatihan penggunaan digital marketing melalui social media dan e-commerce sebelumnya dilakukan juga pada istri nelayan di desa Desa Mayangan, Kota Probolinggo (Azizah, 2019). Dari pelatihan tersebut, dinilai memberikan manfaat dan respon positif bagi peserta pelatihan. Hasil pengabdian yang lainnya, yaitu optimalisasi media sosial sebagai alat promosi untuk desa wisata. Berdasarkan hasil pengabdian tersebut, media promosi media sosial, sangat efektif untuk menarik wisatawan untuk datang berkunjung (Setyowardhani et al., 2019). Berdasarkan hasil survei awal yang telah dilakukan, Kampung Batik Kembang Turi Blitar belum mempunyai media komunikasi dan media komersialisasi secara digital. Selain itu, kebanyakan anggota paguyuban belum mahir menggunakan teknologi informasi. Oleh karena itu, perlu diberikan sosialisasi, pelatihan dan pendampingan dalam 
pemanfaatan teknologi informasi, yang dalam hal ini penulis wujudkan dalam bentuk kegiatan pengabdian kepada masyarakat. Kegiatan pengabdian masyarakat mengenai pemanfaatan digital marketing di Kampung Batik Kembang Turi Blitar ini diharapkan dapat memberikan pengenalan, inspirasi, menumbuhkan motivasi dan pemahaman dalam memanfaatkan digital marketing terutama dalam penggunaan social media dan e-commerce untuk menjalankan bisnisnya.

\section{METODE}

\section{Metode Pelaksanaan}

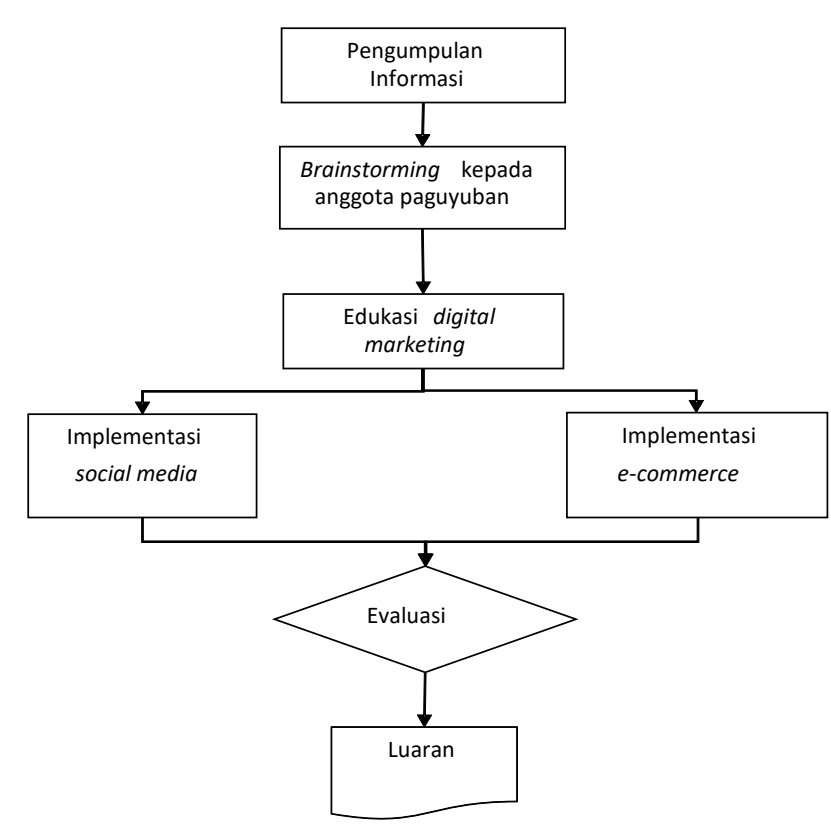

Gambar 3. Metode Pelaksanaan

Metode pelaksanaan kegiatan pengabdian kepada masyarakat ini dibagi dalam tiga tahapan yaitu;

a. Tahap Pendahuluan: pada tahap ini tedapat dua kegiatan yang meliputi pengumpulan informasi dan brainstorming,

b. Tahap Pelaksanaan Kegiatan: pada tahap ini terdapat dua kegiatan yang meliputi edukasi dan implementasi.

c. Tahap Terakhir: evaluasi kegiatan

\section{Analisa Kebutuhan}

Pada awal kegiatan, dilakukan pengumpulan informasi untuk mengetahui kondisi dan kebutuhan riil. Setelah pengumpulan informasi, kemudian dilaksanakan sesi brainstorming untuk menggali permasalahan dan kemungkinan solusi. Dari hasil pendahuluan kegiatan diperoleh analisa kebutuhan sebagai berikut;

a. Belum adanya media digital yang digunakan Kampung Batik Kembang Turi Blitar dalam upaya komersialisasi produk;

b. Kurangnya pengetahuan dan pemahaman anggota paguyuban mengenai pentingnya digital marketing bagi usaha mereka;

c. kurangnya kemampuan anggota paguyuban dalam menggunakan digital marketing dengan memanfaatkan social media maupun e-commerce.

\section{Rancangan Instruksional}

Pelaksanaan kegiatan dilakukan dengan memberikan pengenalan dan edukasi 
menggunakan metode ceramah dan diskusi. Pendampingan dalam mengimplementasikan social media dan e-commerce sebagai media komersialisasi produk diberikan dalam bentuk tutorial, tanya jawab, demonstrasi dan praktik mulai dari menginstal aplikasi, mendaftar, membuat akun resmi, mengunggah konten menarik sehari-hari, dan mengoptimalkan penggunaan SEO pada social media dan e-commerce.

\section{Rancangan Evaluasi}

Adapun evaluasi dilakukan dengan mengacu pada beberapa indikator ketercapaian dan tolak ukur yang telah ditentukan, yang tampak pada Tabel 1.

Tabel 1. Rancangan Evaluasi

\begin{tabular}{ll}
\hline Tujuan & Indikator Ketercapaian \\
\hline $\begin{array}{l}\text { Peserta mengenal } \\
\text { digital marketing dan } \\
\text { manfaatnya }\end{array}$ & $\begin{array}{l}\text { Peserta mengenal apa saja media } \\
\text { digital marketing, manfaat dan } \\
\text { kelebihan digital marketing }\end{array}$
\end{tabular}

Tolok Ukur

Peserta mampu menyebutkan media digital marketing yang dapat digunakan sebagai sarana komersialisasi produk, mampu menyebutkan manfaat dan kelebihan digital marketing

Peserta mampu dan Peserta mampu dan terampil terampil menggunakan social media untuk komersialisasi produk

Peserta mampu dan terampil menggunakan $e$ commerce dalam mempromosikan produk menggunakan social media. Mulai dari menginstal aplikasi, mendaftar, membuat akun resmi, mengunggah konten menarik sehari-hari, dan mengoptimalkan penggunaan SEO

Peserta mampu dan terampil menggunakan e-commerce. Mulai dari menginstal aplikasi, mendaftar, membuat akun resmi, mengunggah konten menarik sehari-hari, dan mengoptimalkan penggunaan SEO
Peserta memiliki aplikasi media sosial dan memiliki akun resmi serta telah mengunggah kontenkonten menarik dalam social media

Peserta memiliki aplikasi ecommerce dan memiliki akun pada media e-commerce serta telah mengunggah gambar produk yang dijual

\section{HASIL DAN PEMBAHASAN}

\section{Pendahuluan Kegiatan}

Tahap pendahuluan kegiatan dilakukan dengan menggali informasi tentang Kampung Batik Kembang Turi Blitar yang diperoleh dari Lurah Turi. Kampung Batik Kembang Turi Blitar diresmikan pada tanggal 1 Oktober 2018, dengan jumlah anggota yang tergabung dalam Paguyuban Kampung Batik Kembang Turi Blitar Blitar sebanyak 31 orang, dengan rata-rata anggota adalah para ibu rumah tangga di Kelurahan Turi. Tahapan selanjutnya yaitu brainstorming; sebuah upaya kreatif dalam menemukan permasalahan dan menyelesaikannnya. Pada sesi ini, diajukan permasalahan terkait upaya penjualan produk Batik Kembang Turi Blitar dan beberapa kemungkinan solusi untuk mengatasinya. Dari hasil brainstorming diperoleh informasi;

a. Penjualan produk yang telah dilakukan yaitu melalui pameran-pameran yang diadakan baik di dalam kota maupun luar kota Blitar. Selain itu, produk batik dipamerkan dan dijual di galeri batik yang berada di Kelurahan Turi Kota Blitar,

b. Promosi yang dilakukan masih mengandalkan cara tradisional yaitu terbatas melalui word of mouth sehingga tidak dapat menjangkau pasar yang lebih luas,

c. Kemungkinan penggunaan social media dan e-commerce untuk komersialisasi produk Batik Kembang Turi. 


\section{Pelaksanaan Kegiatan}

Pelaksanaan kegiatan meliputi kegiatan edukasi dan implementasi. Pada tahap edukasi diberikan materi pengenalan tentang dunia digital, digital marketing, pengenalan media yang dapat dimanfaatkan untuk menerapkan digital marketing, dan contoh sukses pelaku usaha yang telah menerapkan digital marketing. Contoh-contoh diberikan untuk memberikan inspirasi dan motivasi untuk menggunakan teknologi digital.

Tahapan selanjutnya yaitu implementasi yang dilakukan melalui dua kegiatan sekaligus yaitu, implementasi social media dan implementasi e-commerce. Adapun langkah-langkah kegiatan yaitu;

a. Pemberian bantuan smartphone yang digunakan sebagai alat pemasaran digital. Nantinya smartphone inilah yang digunakan untuk mengelola seluruh akun social media dan e-commerce milik Kampung Batik Kembang Turi Blitar,

b. Memberikan tutorial dan praktik tentang pembuatan akun e-mail Kampung Batik Kembang Turi Blitar yang akan digunakan untuk membuat akun-akun pada media digital lainnya,

c. Memberikan tutorial dan praktik tentang pembuatan akun social media, yaitu Facebook dan Instagram dan e-commerce yaitu Tokopedia. Facebook dan Instagram merupakan social media dengan pengguna terbanyak nomor dua dan tiga di Indonesia. Youtube sebagai social media pertama dengan jumlah pengguna terbanyak di Indonesia tidak digunakan, karena keterbatasan dalam pembuatan konten berbentuk video. Tokopedia dipilih dari hasil brainstorming karena dianggap sebagai platform yang paling familiar di kalangan peserta.

d. Memberikan tutorial dan praktik mengunggah konten berupa foto produk maupun foto kegiatan yang ada di Kampung Batik Kembang Turi Blitar. Ada beberapa foto produk yang telah ada sebelumnya, namun foto kurang manarik sehingga tim memberikan pendampingan pula terkait pengambilan foto produk,

e. Memberikan tutorial dan praktik serta tips optimalisasi social media, mulai dari pembuatan profil, keyword, penggunaan hashtag dan penulisan caption yang menarik,

f. Kegiatan pendampingan dalam mengunggah konten di social media dan mengunggah foto produk di e-commerce dilakukan beberapa kali selama 2 bulan sampai peserta terampil menggunakan social media.

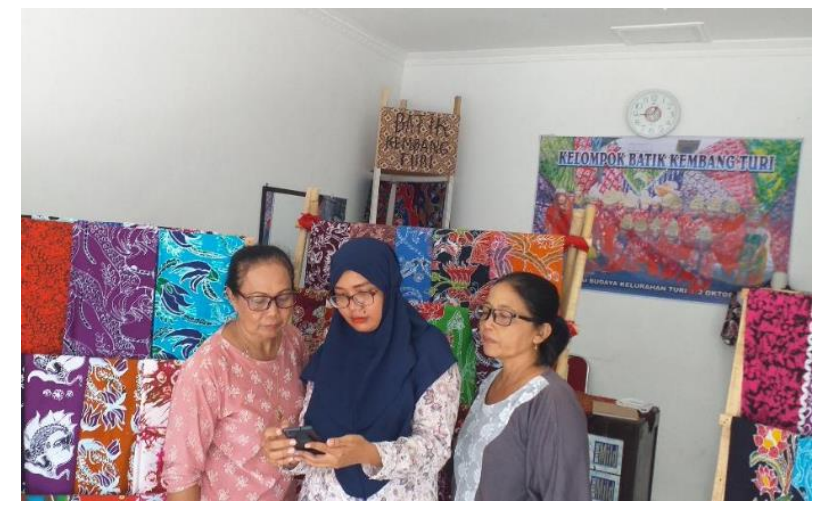

Gambar 4. Praktik penggunaan social media dan e-commerce

\section{Evaluasi Kegiatan}

Berdasarkan kegiatan pengabdian yang telah dilakukan, pelaksanaan kegiatan berjalan lancar sesuai dengan program yang telah direncanakan. Evaluasi kegiatan dilakukan melalui wawancara dengan peserta dan melihat respon peserta secara langsung selama pelaksanaan kegiatan. Tahap evaluasi menunjukkan hasil yang positif sesudah dilaksanakan pengabdian. Peserta mampu menyebutkan media digital marketing yang dapat digunakan sebagai sarana komersialisasi produk, mampu menyebutkan manfaat dan kelebihan digital marketing serta berhasil mengunggah konten pada social media dan foto produk pada platform e-commerce. Hasil dari pembuatan akun social media dan e-commerce ini diantaranya jumlah follower yang terus bertambah dan semakin banyak wisatawan dari luar daerah yang datang berkunjung ke Kampung Batik Kembang Turi Blitar sekaligus membeli produknya. 


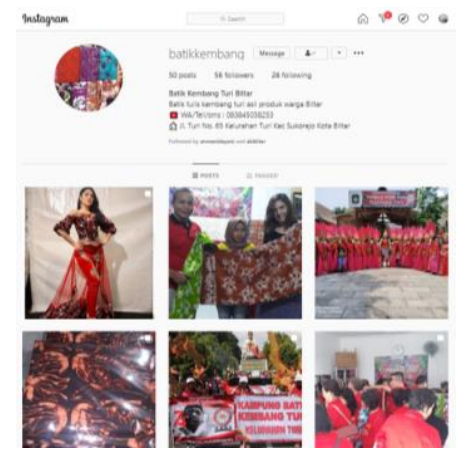

(a)

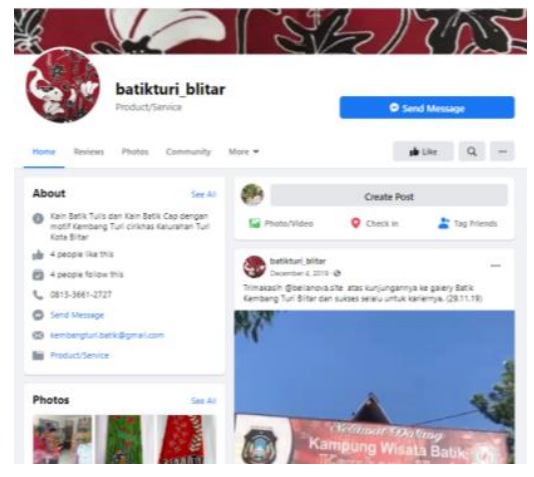

(b)

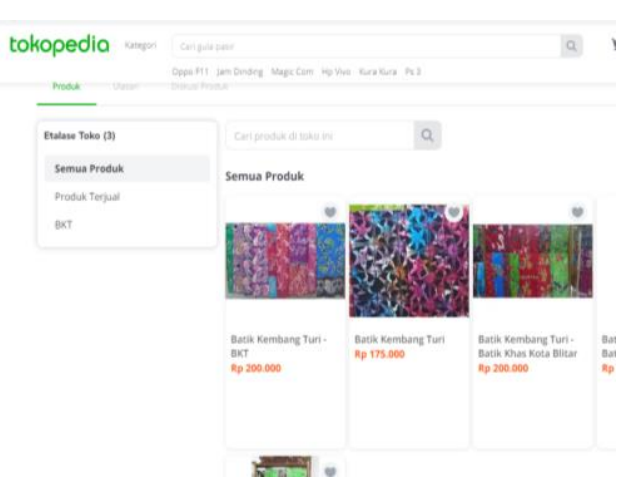

(c)

Gambar 5 Akun yang berhasil dibuat (a) Instagram (b) Facebook (c) Tokopedia

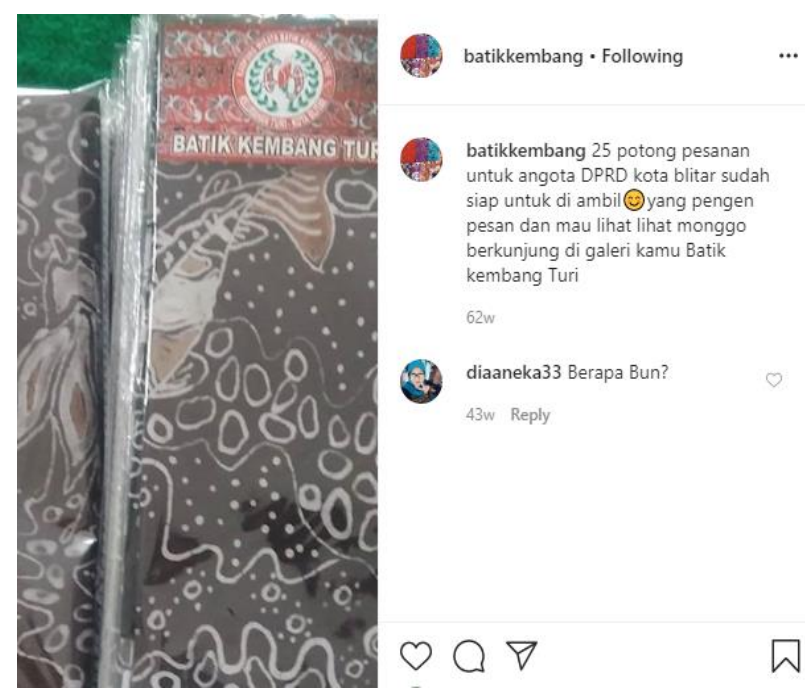

Gambar 6 Penulisan caption pada konten yang diunggah

Hasil positif lainnya juga dapat dilihat dari antusiasme peserta selama mengikuti kegiatan. Terkait pelaksanaan kegiatan diperoleh informasi bahwa materi yang diberikan pada kegiatan pendampingan ini jelas, mudah diikuti dan sesuai dengan tujuan pelatihan dan berharap untuk ke depannya ada kegiatan lagi dalam bentuk peningkatan ketrampilan.

\section{DAFTAR PUSTAKA}

Azizah, N. (2019). Pelatihan Pemberdayaan Istri Nelayan Melalui Pelatihan Digital Marketing Strategy (DMS) Darah Biru. Dinamisia : Jurnal Pengabdian Kepada Masyarakat, 3(1), 131141. https://doi.org/10.31849/dinamisia.v3i1.2675

Balan, S., \& Rege, J. (2017). Mining for social media: Usage patterns of small businesses. Business Systems Research, 8(1), 43-50. https://doi.org/10.1515/bsrj-2017-0004

Bukht, R., \& Heeks, R. (2018). Defining, conceptualising and measuring the digital economy. International Organisations Research Journal, 13(2), 143-172.

https://doi.org/10.17323/1996-7845-2018-02-07

Inilah e-Commerce yang Paling Banyak Dikunjungi di 2017 / Marketeers - Majalah Bisnis \& Marketing Online - Marketeers.com. (n.d.). Retrieved May 12, 2020, from

https://marketeers.com/e-commerce-paling-banyak-dikunjungi/

Mengenal Batik Tutur, Batik Khas Blitar Warisan Nenek Moyang - BALITAR.ID. (n.d.). Retrieved May 16, 2020, from https://balitar.id/mengenal-batik-tutur-batik-khas-blitar-warisannenek-moyang/ 
Pandey, N., Nayal, P., \& Rathore, A. S. (2020). Digital marketing for B2B organizations: structured literature review and future research directions. Journal of Business and Industrial Marketing, December. https://doi.org/10.1108/JBIM-06-2019-0283

Setyowardhani, H., Susanti, H., \& Riyanto. (2019). Optimalisasi Media Sosial sebagai Alat Promosi untuk Desa Wisata Lebakmuncang. Dinamisia : Jurnal Pengabdian Kepada Masyarakat, 3, 19-26. https://doi.org/10.31849/dinamisia.v3i2.2848

Statistik, B. P. (2019). Statistik E-Commerce 2019.

Taiminen, H. M., \& Karjaluoto, H. (2015). The usage of digital marketing channels in SMEs. Journal of Small Business and Enterprise Development, 22(4), 633-651. https://doi.org/10.1108/JSBED-05-2013-0073

Zekos, G. I. (2003). MNEs, globalisation and digital economy: legal and economic aspects. Managerial Law, 45(1/2), 1-296. https://doi.org/10.1108/03090550310770875 